\title{
Communication Apprehension among Nilai College Students
}

\author{
Uryani Sabri \\ University Putra Malaysia \\ E-mail: suryanibintisabri@gmail.com \\ Teah Yu Qin \\ University Putra Malaysia
}

Doi:10.7575/aiac.alls.v.5n.5p.46

URL: http://dx.doi.org/10.7575/aiac.alls.v.5n.5p.46
Received: $15 / 06 / 2014$

Accepted: 14/08/2014

\begin{abstract}
In recent years, ESL studies have found that most graduates are critically lacking in speaking skills, especially among Malaysia graduates. With constant struggle to communicate in English which is their second language, they become apprehensive when the need to use the language arises. The purpose of this study is to investigate communication apprehension among students from Nilai University College and whether the communication apprehension would differ among students from different semester. The respondents for the study were two classes from two different semesters with 30 students each. In this study, the PRCA-24 was used to collect data. By conducting this study, it is hoped to provide valuable insights on students' communication apprehension.
\end{abstract}

Keywords: Communication apprehension; group discussion; meeting; interpersonal communication; public speaking

\section{Background of the study}

Oral communication competence is highly prized for career success and most of higher learning institutions have awakened to the importance of oral communication in curriculum. A study by Isarji and Ainol (2008) on Malaysian Employers Federation found that Malaysian employers to rate English competency as the most critical skill lacking among graduates. In another study conducted by Malaysian Government, it was discovered that about 60,000 Malaysian graduates were unemployed due to a lack of English language competency and poor oral communication skills (Malaysian Today, 2005).

According to Mustapha, Ismail, Ratan and Elias (2010), Malaysia graduates still struggle to speak in English. Thus, they become apprehensive when are required to communicate in English language.

\section{Statement of the problem}

In preparing Nilai University College students for the real world, they are needed to be equipped with skills that are aligned with the industry needs. Employers placed a high degree of importance on communication skills and the ability to give formal presentations (Pittenger, Miller, \& Mott, 2004).

Since communication apprehension (CA) is the most often cited trait that influences oral communication and presentation delivery, it might be the cause of the graduates' inability to communicate well in target language. Many graduates that obtained excellent grades in the English language course have sound knowledge on writing and reading component of English language, but they are unable to communicate effectively with others due to high level of communication apprehension.

As Horwitz (1986) explains, apprehension is a major obstacle to overcome in learning to speak another language. Therefore, this study is conducted to investigate communication apprehension among students from Nilai University College and whether the communication apprehension would differ among students in different semester.

\section{Purpose of the Study}

The purpose of this study is to investigate communication apprehension among students from Nilai University College, firstly whether the communication apprehension would differ between students from semester 4 and semester 6 and secondly whether CA would differ between four different communication contexts.

\section{Research Questions}

Based on the purpose of the study, the following research questions will be explored:

1. Is there any significant difference in the level of communication apprehension between semester 4 and semester 6 respondents? 
2. Is there any significant difference in communication apprehension ofthe respondentsin the four contexts (group discussion, meetings, interpersonal conversations, and public speaking)?

\section{The Scope of the Study}

This study will involve two classes from different semesterwith equal number of students.

\section{Significance of the study}

This study investigates the students' communication apprehension in two different semesters. This study is also significant to the lecturers of English in helping them design or inculcate new teaching and learning strategies in achieving the goal of Outcome Based Education (OBE).

\section{Limitations of the Study}

There are two limitations in this study. Firstly, the study design will employ the use of nonprobability sampling. Thus, there is noguarantee that each element in the large population of the university students will be represented in the nonprobability sample (Leedy\&Ormrod, 2001).

Secondly, due to time constraints, the scope of the study was limited to only one semester 4 class and one semester 6 class in Nilai UniversityCollege.

\section{Literature Review on Communication Apprehension}

Communication apprehension is defined as "an individual's level of fear of anxiety associated with either real or anticipated communication with another person or persons" (Richmond \&McCrosky, 1989). Speakers feel nervous and tense while they are speaking in public. The problems include lack of confidence, afraid of making mistakes and lack of speaking skills. Research have shown that communication apprehension can be reduced by upgrading skills, changing cognitions, getting people to relax and/or altering the way one envisions oneself as a speaker.

Several findings also discovered that learners expressed more apprehension over speaking than any other skills especially for non-native speakers. A study conducted by Keaten, Kelly, \&Pribyl (1997) found that communication apprehension levels of Japanese elementary and secondary school students learning English as a second language have increased from primary to secondary school. While delivering oral presentation, besides focusing on the actual task, they need to translate their thought from native language to English language. Hence, this may also interfere with the students' ability to demonstrate the level of their accurate knowledge. Furthermore, according to Preiss (1989), communicative apprehension negatively affects students' academic success

\section{Population and Sampling Procedure}

The study was conducted in Nilai University College. A purposive sample of two classes fromtwo different semester with equal number of students ( 30 students) hadbeen chosen as the samples for this research.

\section{Instrumentation}

The PRCA-24 (McCroskey 1982) is a validated instrument that has been used repeatedly as a measure of communication apprehension (Aly and Islam, 2005). This instrument was designed to assess feelings about communicating in four contexts which are in (a) group discussion, (b) meetings, (c) interpersonal conversations, and (d) public speaking.

McCroskey et al. (1985) reported that the PRCA-24 is high in internal consistency, with alpha reliability estimates ranging from .93 to .95 . The instrument also demonstrated considerable stability across time; test-retest reliability coefficients greater than .80 have been reported by Rubin, Graham and Mignerey (1990).

Several studies have been conducted to determine the content validity and construct validity of PRCA-24. In terms of content validity, Beatty (1987) found that the public-speaking score in PRCA-24 predicts general avoidance and withdrawal behaviours whereas Beatty, Frost and Stewart (1986) discovered that the score can predict speech duration. The construct validity of PRCA-24 as studied by Keaten, Kelly, Begnal, Heller and Walker (1993) noted that it was correlated strongly to reticence. Further study by Keaten and Kelly (1994) observed that PRCA-24 was correlated significantly to reports of communication competence

\section{Data Analysis}

Data were analysed using IBM SPSS (Statistical Product and Service Solutions) 21. A descriptive analysis was performed to compute the means and standard deviations for each item. An independent t-test was used to compare communication apprehension between semester 4 and semester 6 .

\section{Findings and Discussion}

The means and standard deviation for the study variables are shown in Table 1.1. The scale measurement used in this study was 5-point Likert scale. For clarity of explanation, the mean scores were divided into three levels which are low, moderate and high. Mean values of less than 2.49 was categorized as "low", mean values between 2.50 and 3.49 was categorized as "moderate", while mean values of 3.50 to 5.00 was categorized as "high". 
Table 1.1. Mean scores and Standard Deviation for the Respondents' Semester

\begin{tabular}{rcc}
\hline Semester & Mean & Std. Deviation \\
\hline 4 & 3.1639 & .32050 \\
6 & 2.9722 & .33909 \\
\hline
\end{tabular}

The mean scores did not indicate any significant differences between semester 4 and semester 6 communication apprehension. From the output in Table 1.1, it is evident that the mean and standard deviations of the two groups were fairly close since there was not much difference between semester 4 (3.16) and semester 6 (2.97) communication apprehension.

Table 1.2. Mean scores and Standard Deviation for the Context

\begin{tabular}{lll}
\hline Context & Means (M) & Std. Deviation (SD) \\
\hline & & \\
Group Discussion & 3.1694 & .42684 \\
Meetings & 3.1028 & .51447 \\
Interpersonal Communication & 2.9861 & .43319 \\
Public Speaking & 3.0139 & .53966 \\
\hline
\end{tabular}

There were similar responses of apprehension amongst the four contexts. The mean value for group discussion (3.16) and meetings (3.10) was rather moderate. This suggests that the sampled respondents perceived that they might feel they were being supported by their peers during these two contexts. Even though interpersonal communication (2.98) has similar mean values as group discussion and meetings which was moderate, it can be seen that the respondents experience least apprehension compared with the other three contexts. The mean value for public $\operatorname{speaking}(3.01)$ was moderate as well. Thus, the mean scores of the context did not indicate any significant differences of communication apprehension amongst the four contexts.

\section{Conclusion}

The study examined communication apprehension of students from two different semesters in Nilai University College. The results revealed that there are no significant differences in communication apprehension between semester 4 and semester 6 . This is possibly due to the reason that semester 4 and semester 6 are just two semesters apart, hence not much difference in English proficiency level.

Next, among the four contexts of communication apprehension, the mean values were found similar. However, the mean value of communication apprehension in group discussion is slightly higher than the others. The reason for this is possibly respondents' lack of confidence when interacting with other people using English. In addition, unlike public speaking that allows them to prepare their speech beforehand, meetings or group discussions requires the students to be able to speak English spontaneously while maintaining the conversation.

Thus, with the findings in this study, it is hoped to help lecturers of English in attempting to improve learning environments by creating relaxed atmospheres for students, which can make them feel safe to speak or express their views.

\section{References}

Aly, I.\& Islam M. (2005). Factors affecting oral communication apprehension among business students: An empirical study. J. Amer.Acad. Bus. 6(2) 98-103.

Brown, G. \& Bull, J., \&Pendlebury, M. (1997).Assessing student learning in highereducation. London: Routledge

Daly, J. A. and Miller, M. D. (1975) Further studies on writing apprehension: SAT scores, successexpectations, willingness to take advanced courses and sex differences, Research in the Teaching of English, 9, pp. 249-253

Fill, K. \& R. Ottewill. (2006). Sink or swim: Taking advantage of developments in video streaming. Innovations Ed. Teaching Internat. 43(4) 397-408.

Hassall, T., J. Joyce, R. Ottewill, J. Arquero.\& J. Donoso. (2000). Communication apprehension in UK and Spanish business and accounting students. Ed. Training 42(2) 93-100. 
Heaney, B. The assessment of educational outcomes(Report No.EDO-JC-90-01). Office of Educational Research and Improvement.(ERIC Document Reproduction Service No.ED 321834), 1990.

Horwitz, E. K., Horwitz, M. B., \& Cope, J. (1986).Foreign language classroom anxiety. The Modern Language Journal, $70(2), 125-132$

IsarjiSarudin ,AinolMadziahZubairi. 2008. Language Needs of Marketable Graduates: Industry's Expectations and University Initiatives. Paper presented at the International Language Conference, 3rd-5th March 2008, CELPAD, IIUM, Legend Hotel, Kuala Lumpur.

Keaten, J.A.,\& Kelly, L.A,. (1994) Negatives thoughts, conditions anxiety and skills deficit.Paper presented at the Annual Meeting Of The Speech Association, New Orleans, L.A, USA

Keaten, J.A..,Kelly, L.A.,Begnal, C., Heller, D., \& Walker, A.,(1993) Development of instrument to measure reticence. Paper presented at the Annual Meeting Of The Speech Association, New Orleans, L.A, USA

Kilfoil, W. R., \& Van der Walt, C. (1997). Learn 2 teach: English language teaching in a multilingual context. Pretoria: J. L. Van Schaik

Kudlas, J.M., 1994, 'Implications of OBE: what you should know about outcomes-based education', The Science Teacher, 61(5), pp. 32-5

Leedy, P., \&Ormrod, J. (2001).Practical research. Planning and design. (7th Ed.) Upper Saddle River, N.J.: MerrillPrentice Hall.

Malaysia. Department of Polytechnic Education. AE101 communicative English Syllabus Document. Version;080510_1.2 . 2010.

Malaysia has 60,000 graduates unemployed. (2005). Retrieved fromhttp://www.malaysia-today.net/Bloge/2005/11/malaysia-has-60000 undergraduates.htm

Mustapha W.Z, Ismail N, Ratan Sigh D.S, \& Elias. S. (2010) ESL Students Communication Apprehension And Their Choice Of Communicative Activities .

McCroskey, J. C. (1984). The communication apprehension perspective. J. Daly, J. McCroskey, eds. Avoiding Communication. Sage Publications, Beverly Hills, CA, 13-38.

McCroskey, J. C. (1977). Oral communication apprehension: A summary of recent theory and research. Human Comm. Res. 4(1) 78-96.

McCroskey, J. C. (1982). An Introduction to Rhetorical Communication, 4th ed. Prentice- Hall, Englewood Cliffs, NJ.

Pettinger, K., Miller, M., \& Mott, J. (2004). Using real-world standards to enhancestudentse presentation skills. Business Communication Quarterly, 67(3), 327-336

P'Rayan A,.\& T. Shetty,R. (2008). Developing Engineering Students' Communication Skills by Reducing theirCommunication Apprehension.English for Specific Purposes World (www.esp-world.info), Issue 4 (20), Volume 7.

Preiss, R. W. 1989. The nature and correlates of receiver apprehension. Paper presented at the meeting of the Speech Communication Association, San Francisco, CA.

Pribyl, C. B., Keaten, J., \& Sakamoto, M. (2001). The effectiveness of a skills-based program in reducing public speaking anxiety. Japanese Psychological Research, 43(3), 148-155.

Richmond, V. P., \& McCroskey, J. C. (1989).Communication: Apprehension, Avoidance, and Effectiveness, 2nd edition. Scottsdale, AZ: GorsuchScarisbrick

Rubin, R.B., Graham, E.E., \&Mignerey, J.T., (1990). A longitudinal college students' communication competence.Communication Education, 1-14. 